Agrovoc descriptors: glycine max, soybeans, varieties, selection, field experimentation, crop management, cultivation, spacing, growth period, crop yield

Agris category code: F01, F08

\title{
Influence of row spacing on the yield of ten cultivars of soybean (Glycine max (L.) Merrill)
}

\author{
Darja KOCJAN AČKO ${ }^{1}$, Stanislav TRDAN ${ }^{2}$
}

Received August 08, 2008; accepted October 28, 2008.

Delo je prispelo 8. avgusta 2008; sprejeto 28. oktobra 2008.

\section{ABSTRACT}

In the period 2001-2005 block field trials with ten soybean cultivars (Glycine max (L.) Merrill): Aldana, Borostyan, Essor, Ika, Kador, Major, Nawiko, Olna, Tarna and Tisa with three repetitions have been designed on the experimental field at the Biotechnical Faculty in Ljubljana with the purpose of studying the influence of sowing density on crop yield. Planting of soybean was performed manually each year in the beginning of May using the $50 \mathrm{~cm}$ row spacing (wide rows) and $25 \mathrm{~cm}$ spacing (narrow rows), the distance between seeds in a row was $15 \mathrm{~cm}$. In each case of row spacing, the soybean cultivar and the year of the experiment influenced the mean yield of the soybean. For the dense sowing, the significantly higher yield of soybean $(3428 \mathrm{~kg} / \mathrm{ha})$ was detected compared to the thin sowing $(2690 \mathrm{~kg} / \mathrm{ha})$. The significant influence of the cultivar was found in every year in case of the thin sowing, where the yield in the 2001 (the year of the drought) was significantly lower compared to other years. For the thin sowing, the most productive cultivar was the Borostyan $(3974 \mathrm{~kg} / \mathrm{ha})$, the lowest mean yield was recorded for the cultivar Aldana (1472 kg/ha). For the dense sowing, significantly higher soybean yield was confirmed in 2005 (3760 kg/ha), compared to the years 2002 (3145 $\mathrm{kg} / \mathrm{ha}$ ) and $2003(3239 \mathrm{~kg} / \mathrm{ha})$, when the yields were significantly lower. The cultivar Aldana recorded the lowest yield $(2110 \mathrm{~kg} / \mathrm{ha})$ also in the case of dense sowing, while under the same growing conditions, the cultivar Tisa $(5171 \mathrm{~kg} / \mathrm{ha})$ proved to be the most productive cultivar. Considering the length of the growing period and the yield, the medium late cultivars Borostyan, Essor, Tarna, Major and Olna and the medium early cultivar Nawiko could be recommended for sowing in central parts of Slovenia. Despite higher productivity of Tisa, Ika and Kador cultivars, their late maturity is less suitable for machine harvesting on lager land areas. Based on our data on productivity, growing period and other economically significant characteristics of soybean cultivars, together with selected row spacing, the experts will be able to suggest to producers cultivars and production practises to ensure high and dependable yields of soybean.

Key words: soybean, Glycine max, cultivars, field trials, row spacing, growth conditions, growth period, grain yield

\section{IZVLEČEK}

\section{VPLIV MEDVRSTNEGA RAZMIKA NA PRIDELEK DESETIH KULTIVARJEV SOJE (Glycine max (L.) Merrill)}

V obdobju 2001-2005 so bili na poskusnem polju Biotehniške fakultete $\mathrm{v}$ Ljubljani zasnovani bločni poljski poskusi $\mathrm{z}$ desetimi kultivarji soje (Glycine max (L.) Merrill), in sicer: Aldana, Borostyan, Essor, Ika, Kador, Major, Nawiko, Olna, Tarna in Tisa $\mathrm{v}$ treh ponovitvah, $\mathrm{z}$ namenom preučitve vpliva gostote setve na pridelek zrnja. Setev soje je bila izvedena vsako leto na začetku maja, in sicer ročno, na medvrstna razmika $50 \mathrm{~cm}$ (redka setev) in $25 \mathrm{~cm}$ (gosta setev), razmik med semeni v vrsti pa je bil $15 \mathrm{~cm}$. Pri obeh medvrstnih razmikih sta na povprečni pridelek soje vplivala kultivar in leto poskusa. Pri gosti setvi je bil ugotovljen signifikantno večji pridelek soje (3428 kg/ha) kot pri redki setvi $(2690 \mathrm{~kg} / \mathrm{ha})$. Signifikanten vpliv kultivarja na pridelek se je pokazal v vseh letih pri redki setvi, pri čemer je bil pridelek v letu 2001 (sušno leto) signifikantno manjši kot $\mathrm{v}$ ostalih letih. Najbolj roden kultivar pri redki setvi je bil Borostyan (3974 kg/ha), najmanjši pridelek pa smo ugotovili pri kultivarju Aldana $(1472 \mathrm{~kg} / \mathrm{ha})$. Pri gosti setvi smo potrdili signifikantno največji pridelek soje v letu $2005(3760 \mathrm{~kg} / \mathrm{ha}), \mathrm{v}$ primerjavi z letoma 2002 $(3145 \mathrm{~kg} / \mathrm{ha})$ in 2003 (3239 kg/ha), ko sta bila pridelka signifikantno manjša. Kultivar Aldana (2110 kg/ha) je imel najmanjši pridelek tudi pri gosti setvi, medtem ko je bil v istih rastnih razmerah najbolj roden kultivar Tisa $(5171 \mathrm{~kg} / \mathrm{ha})$. Glede na dolžino rastne dobe in velikost pridelka lahko za setev $\mathrm{v}$ osrednji Sloveniji priporočamo srednje pozne kultivarje Borostyan, Essor, Tarna, Major in Olna ter srednje zgodnji kultivar Nawiko. Kljub večji produktivnosti kultivarjev Tisa, Ika in Kador, je njihova pozna zrelost manj ustrezna pri strojnem spravilu na večjih zemljiščih. Le na podlagi poznavanja produktivnosti, dolžine rastne dobe in drugih gospodarsko pomembnih lastnosti kultivarjev soje pri izbranem medvrstnem razmiku, bodo lahko strokovnjaki svetovali pridelovalcem, tako, da bo pridelek zrnja velik in zanesljiv.

Ključne besede: soja, Glycine max, kultivarji, poljski poskusi, medvrstni razmik, rastne razmere, dolžina rastne dobe, pridelek zrnja

\footnotetext{
${ }^{1}$ Jamnikarjeva 101, SI-1111 Ljubljana, e-mail: darja.kocjan@bf.uni-lj.si

${ }^{1}$ ibid.
} 


\section{INTRODUCTION}

Soybean (Glycine max (L.) Merrill), the most important protein legume and oilseed with approximately 100 million hectares planted lands around the world, is only grown on few tens of hectares of lands in Slovenia. For decades Slovenia has been importing vegetable proteins for animal feed, however soybean could be added to human diet as well. It is important not to neglect to the benefits arising from soybean's abiliy to fix nitrogen, as a leguminous plant in the crop rotation (Čremožnik, 2004; Štepic, 2004; Kocjan Ačko, 2005).

Potential soybean producers are mostly organic farmers, who are facing the dilemmas of selecting the suitable planting and harvesting times, sowing density (crops sown usually to the $50 \mathrm{~cm}$ row spacing are often very weedy). Problems are also caused by a small selection of cultivars that have been tested in Slovenia and the lack of machine equipment for the harvesting of grains. The type of sowing and the size of row spacing (sowing density) have an important influence on grain yield. To assure and reach the production potentials, we have to establish the length of the growing period and optimum sowing density for the cultivar that we are planning to grow on certain area. According to the research results (Vratarić, 1986; Carlson, 1973; Moore, 1991; Lueschen, 1992; Devlin, 1995; Elmore, 1998; Holshouser and Whittaker, 2002; Pedersen and Lauer, 2003; Štepic, 2004) the yields of grain, grown in smaller row spacing (10 to $25 \mathrm{~cm})$, were higher compared to greater row spacing $(50$ to $90 \mathrm{~cm})$. The latter finding needs to be tested for individual cultivars under the conditions of their planned production and considering also their growth habit (capability of branch formation and the length of the growing period). After the year 2004, Slovenian producers can sow any cultivar listed in the Common catalogue of the European Union also in Slovenia, which caused a drop in the number of cultivars under the official testing, which causes shortage of relevant information on economically significant characteristics of the cultivars, mostly for the crops that we are trying to re-introduce due to the needs of the crop rotation or alternative uses and ways of production and nutrition. Since numerous foreign cultivars are not suitable for the production in Slovenia (some of them would not reach their full harvest maturity) we can not entirely rely on the descriptions of their characteristics coming from the areas where they are traditionally grown and which are not entirely comparable to Slovenia.

The purpose of the soybean field trials was to determine the influence of the row spacing to the yield of ten soybean cultivars. Results of the testing of soybean cultivars at the experimental field of Biotechnical Faculty will, at least partly, replace the testing of these cultivars in official field trials and help us select the suitable cultivars according to the length of the growing period and selection of the row spacing that assure higher yields of grains.

\section{MATERIALS AND METHODS}

\subsection{Study site and background of the research}

In the year 2001 we have designed the experiment on the experimental field at the Biotechnical Faculty in Ljubljana (460.' $\mathrm{N}, 1^{\circ} 31^{\prime} \mathrm{E}, 299 \mathrm{~m}$ altitude) with ten soybean cultivars: Aldana, Borostyan, Essor, Ika, Kador, Major, Nawiko, Olna, Tarna and Tisa (UPOV, 1998; Ileršič and al., 2000; Čremožnik, 2004), under the framework of international cooperation and education with the goal of describing the distinctness, uniformity and stability of soybean cultivars (DUS).

Seed was planted manually in field plots that were $1.5 \mathrm{~m} \mathrm{x} 4.6$ $\mathrm{m}\left(6.9 \mathrm{~m}^{2}\right)$, using the row spacing of $50 \mathrm{~cm}$ and $15 \mathrm{~cm}$ within row spacing at the planting depth of 3 to $5 \mathrm{~cm}$. The field experiment was set up in three replications, with block random distribution of ten cultivars in three repetitions. When monitoring the habitus of the mature plants, we discovered that, in the stage of full blooming or until the pod formation, only the latest cultivars covered the row space, for early and medium late cultivars the rows remained split (UPOV, 1998). Larger than necessary row spacing was the reason that we decided to study the influence of the row spacing on the yield of the crop. In the period from 2002 to 2005 all ten cultivars were sown not only to the $50 \mathrm{~cm}$ row spacing (wide rows), but also at the $25 \mathrm{~cm}$ row spacing (narrow rows), other characteristics of the experiment remained the same as in the year 2001.

\subsection{Studied material}

Soybean cultivars originating from five European countries were used, three were from France (Essor, Kador, Major), two each from Croatia (Ika, Tisa), Hungary (Borostyan, Tarna) and Poland (Aldana, Nawiko) and one from Slovenia (Olna). The cultivars Aldana, Borostyan, Essor, Ika, Nawiko and Tarna are listed in the Common catalogue of the European Union cultivars, the Olna cultivar is - despite its expired registration, still the most widespread cultivar among Slovenian producers.

\subsection{Field experiment}

Soybean was sown in the crop rotation after the cereals - that is on the May 14. 2001, May 7. 2002, May 6. 2003, May 4. 2004 and May 5. 2005. During the pre-sowing preparation the land was fertilized with nitrogen in the amount of $60 \mathrm{~kg} / \mathrm{ha}$ (27-percent KAN), and the seed was not inoculated with the Bradyrhizobium japonicum bacteria. For the thin sowing, three rows were sown on individual parcel and for the dense sowing - six rows. In the case of incomplete emergence we filled in the gaps with repeated sowing when the plants were $5 \mathrm{~cm}$ 
high. We reduced the tweediness, mainly in case of thin sowing by hoeing twice between the rows, first time at the plant height of 10 to $20 \mathrm{~cm}$, the second time before blooming.

\subsection{Field observations and evaluation}

We have monitored the growth and development of all cultivars and in technological ripeness of the grain we manually plucked the pods for each cultivar separately, that was in the period from 4. 9. to 23. 10. in 2001, from 30. 8. to 25. 10 . in 2002 , from 28 . 8. to 15 . 10 . in 2003 , from 29 . 8. to 20. 10. in 2004 and from 28. 8. to 19. 10. in the year 2005 . Pods have been dried in the dryer at the temperature 40 to 45 ${ }^{\circ} \mathrm{C}$, and the grains were then threshed and weighted. For each cultivar we measured humidity on a sample of grains using the humid meter Pfeuffer he 50, and the yield calculated to $8 \%$ moisture, which is the prescribed value for storing the oil seeds. The yield was expressed in $\mathrm{kg} / \mathrm{ha}$. Regarding the date of sowing and harvesting we have calculated the growing period for all tested cultivars and distributed them into maturity groups according to the international classification from 000 to X. (Gagro, 1997; UPOV, 1998). Regarding the length of the growing period the soybean cultivars were arranged into classes - very early cultivars from maturity groups 000 and 00 , remaining on the field from 70 to 80 days; the growing period of early cultivars with the mark 0 is 90 days; medium early to very late are grouped in groups from I. to X. with the ten days difference between the groups.

\subsection{Data analysis}

The data about the yield $(\mathrm{kg} / \mathrm{ha})$ of ten cultivars of soybean were analysed using a general analysis of variance (the results of the yield from both types of sowing in all years were pooled) and individual analysis of variance (the results of the yield for only one type of sowing were treated). Means were separated by Student-Newman-Keuls's multiple range test at $\mathrm{P}$ $<0.05$. Before analysis, each variable was tested for homogeneity of treatment variances. If variances were not homogeneous, data was transformed to $\log (\mathrm{Y})$ before multifactor ANOVA. All statistical analysis was performed with Statgraphics Plus for Windows 4.0 (Statistical Graphics Corp., Manugistics, Inc.). Data is presented as untransformated means $\pm \mathrm{SE}$.

\subsection{Weather conditions in the period 2001 to 2005}

The analysis of mean temperatures and precipitations in Ljubljana from April to October (Monthly..., 2001 to 2005) showed important differences between the years. The year 2001 importantly stands out, when the mean temperatures in July $\left(21.9^{\circ} \mathrm{C}\right)$ and August $\left(22.9^{\circ} \mathrm{C}\right)$ were among the highest and above the long term mean and at the same time both months were very dry (48 $\mathrm{mm}$ and $33 \mathrm{~mm}$ of rain); also October was unusually dry in that year with only $68 \mathrm{~mm}$ precipitations. June, July and August heat was significant for every year of the research, but drastic shortage of rain was recorded only in 2001. Mean monthly air temperatures for September were gradually rising from the year 2001 to 2005 ; also October temperatures were rather high $\left(11.5\right.$ to $\left.13.0^{\circ} \mathrm{C}\right)$, and above the long term mean values with the exception of the October 2002, when the mean temperature was only $8.8{ }^{\circ} \mathrm{C}$. The highest differences in mean annual quantity of precipitations were detected already in summer and moreover in autumn months (rain showers), the highest mean quantity of precipitations in September was recorded in the years 2001 (305 $\mathrm{mm})$ and $2005(294 \mathrm{~mm})$, extremely wet was also October in $2004(287 \mathrm{~mm})$.

\section{RESULTS AND DISCUSSION}

\subsection{Comparison of yields with thin in dense sowing}

Analysis of variance showed a significant influence of the year of the trial, of the cultivar and row spacing to the mean yield of soybean $(\mathrm{P}<0.05)$. The highest yield of ten soybean cultivars was recorded in the year 2005 $(3263 \pm 184 \mathrm{~kg} / \mathrm{ha})$, and significantly the lowest in the years $2002(2899 \pm 94 \mathrm{~kg} / \mathrm{ha})$ and $2003(2952 \pm 162$ $\mathrm{kg} / \mathrm{ha}$ ). The mean yield of soybean, sown to the shorter row spacing was significantly higher $(3428 \pm 126 \mathrm{~kg} / \mathrm{ha})$ compared to the yield of the soybean, sown to larger row spacing $(2690 \pm 86 \mathrm{~kg} / \mathrm{ha})$. This was also the main reason why in continuation we analysed mean yields separately - according to the row spacing.

With the general analysis of variance for the period 2002-2005 we have detected the significant influence of the cultivar $(\mathrm{P}<0.05)$ on the mean yield of soybean for both types of sowing - dense and thin - (Table 1.). Out of all ten cultivars, results showed the lowest yield for the cultivar Aldana $(1791 \pm 137 \mathrm{~kg} / \mathrm{ha})$ and the two most productive cultivars were Borostyan $(4242 \pm 234 \mathrm{~kg} / \mathrm{ha})$ and Tisa $(4216 \pm 309 \mathrm{~kg} / \mathrm{ha})$, which did not differ from one another. Cultivars that significantly different from one another were Ika $(3138 \pm 61 \mathrm{~kg} / \mathrm{ha})$, Tarna $(3381 \pm 123 \mathrm{~kg} / \mathrm{ha})$ and Kador $(3702 \pm 205 \mathrm{~kg} / \mathrm{ha})$. There was no significant difference between the yields of Olna $(2272 \pm 106 \mathrm{~kg} / \mathrm{ha})$ and Major $(2342 \pm 107 \mathrm{~kg} / \mathrm{ha})$ or between Nawiko $(2748 \pm 141 \mathrm{~kg} / \mathrm{ha})$ and Essor $(2757 \pm 148 \mathrm{~kg} / \mathrm{ha})$.

Mean yields varied between the dense and thin sowing for approximately $1900 \mathrm{~kg}$ (Tisa), for $1200 \mathrm{~kg}$ (Kador), for $900 \mathrm{~kg}$ (Essor), for $600 \mathrm{~kg}$ (Aldana and Nawiko) and $500 \mathrm{~kg}$ was the difference for the Borostyan, Olna and Tarna cultivars, the lowest mean difference between the dense and thin sowing, which is approximately $220 \mathrm{~kg}$, was recorded for cultivar Ika (Table 1).

\subsection{Yield of cultivars - thin sowing}

With the use of general analysis of variance we established the significant influence of the year of the trial and of the cultivar to the mean yield of soybean (in both cases $\mathrm{P}<0.05$ ). For the thin sowing we detected no statistically significant differences in the mean yield of cultivars between the years $2002(2654 \pm 131 \mathrm{~kg} / \mathrm{ha})$, 
$2003(2654 \pm 190 \mathrm{~kg} / \mathrm{ha}), 2004(2676 \pm 194 \mathrm{~kg} / \mathrm{ha})$ and $2005(2765 \pm 179 \mathrm{~kg} / \mathrm{ha})$. In the year 2001 the mean yield of the same cultivars was significantly lower $(1814 \pm 136$ $\mathrm{kg} / \mathrm{ha}$ ) compared to other years. Weather conditions, mostly the dry July and August in 2001 are considered the main cause of the differences in the yield.

Table 1: Mean yield of ten cultivars of soybean (Glycine max (L.) Merrill) for thin and dense sowing in block field trials on the experimental field of Biotechnical faculty in Ljubljana (Slovenia) in the period 2002-2005.

\begin{tabular}{|l|c|c|c|c|}
\hline \multirow{2}{*}{ Cultivar } & \multirow{2}{*}{$\begin{array}{c}\text { Mean yield } \\
\text { (kg/ha) - thin and }\end{array}$} & \multicolumn{2}{|c|}{ Mean yield (kg/ha) } & Difference in the \\
\cline { 3 - 4 } & dense sowing & thin sowing & dense sowing & $\begin{array}{c}\text { yield (kg) between } \\
\text { the two sowings }\end{array}$ \\
\hline Aldana & 1791 & 1472 & 2110 & 638 \\
\hline Borostyan & 4242 & 3974 & 4510 & 536 \\
\hline Essor & 2757 & 2296 & 3218 & 922 \\
\hline Ika & 3138 & 3029 & 3248 & 219 \\
\hline Kador & 3702 & 3118 & 4285 & 1167 \\
\hline Major & 2342 & 2160 & 2524 & 364 \\
\hline Nawiko & 2748 & 2448 & 3047 & 599 \\
\hline Olna & 2272 & 2010 & 2535 & 525 \\
\hline Tarna & 3381 & 3135 & 3627 & 492 \\
\hline Tisa & 4216 & 3261 & 5171 & 1910 \\
\hline
\end{tabular}

Considering the mean yield of soybean in the period 2001-2005, significantly the lowest yield was recorded for the cultivar Aldana $(1340 \pm 119 \mathrm{~kg} / \mathrm{ha})$, and significantly most productive was the cultivar Borostyan $(3501 \pm 356 \mathrm{~kg} / \mathrm{ha})$. There was no significant difference among the yields of Ika $(2902 \pm 104 \mathrm{~kg} / \mathrm{ha})$, Tarna $(2911 \pm 161 \mathrm{~kg} / \mathrm{ha})$, Kador $(3048 \pm 96 \mathrm{~kg} / \mathrm{ha})$ and Tisa $(3066 \pm 149 \mathrm{~kg} / \mathrm{ha})$, but their yields were significantly higher compared to Olna $(1981 \pm 100 \mathrm{~kg} / \mathrm{ha})$, Major $(2022 \pm 154 \mathrm{~kg} / \mathrm{ha})$, Nawiko $(2155 \pm 211 \mathrm{~kg} / \mathrm{ha})$ and Essor $(2225 \pm 83 \mathrm{~kg} / \mathrm{ha})$, among which we detected no significant difference as well.

With individual statistical analysis of mean yields of soybean we detected the significant influence $(\mathrm{P}<0.05)$ of the cultivar in every year (Figure 1). In 2001 we confirmed significantly the lowest yield for Aldana $(814 \pm 170 \mathrm{~kg} / \mathrm{ha})$ and Nawiko $(982 \pm 75 \mathrm{~kg} / \mathrm{ha})$ cultivars, significantly the highest yield was recorded for Kador $(2767 \pm 24 \mathrm{~kg} / \mathrm{ha})$, Ika $(2392 \pm 312 \mathrm{~kg} / \mathrm{ha})$ and Tisa $(2288 \pm 8 \mathrm{~kg} / \mathrm{ha})$ cultivars (Figure 1). We detected no significant differences between Olna $(1866 \pm 24 \mathrm{~kg} / \mathrm{ha})$, Essor $(1937 \pm 141 \mathrm{~kg} / \mathrm{ha})$ and Tarna $(2016 \pm 78 \mathrm{~kg} / \mathrm{ha})$, Borostyan (1610 $\pm 6 \mathrm{~kg} / \mathrm{ha})$ and Major (1470 $\pm 48 \mathrm{~kg} / \mathrm{ha})$ cultivars. Their yields were significantly higher compared to cultivars Aldana and Nawiko, while - only for the cultivars Major and Borostyan - it was significantly lower than for the three most productive cultivars.

In 2002 significantly the lowest yield was recorded for Aldana (1848 $\pm 172 \mathrm{~kg} / \mathrm{ha})$, Essor $(2042 \pm 142 \mathrm{~kg} / \mathrm{ha})$, Major (2243 $\pm 29 \mathrm{~kg} / \mathrm{ha})$, Nawiko $(2317 \pm 188 \mathrm{~kg} / \mathrm{ha})$ and Olna $(2358 \pm 391 \mathrm{~kg} / \mathrm{ha})$ and significantly the highest yields were confirmed for the cultivars Ika (2916 \pm 39 $\mathrm{kg} / \mathrm{ha})$, Tarna (3083 $\pm 242 \mathrm{~kg} / \mathrm{ha})$, Borostyan $(3124 \pm 82$ $\mathrm{kg} / \mathrm{ha}$ ), Tisa (3195 $\pm 244 \mathrm{~kg} / \mathrm{ha})$ and Kador (3412 \pm 399 $\mathrm{kg} / \mathrm{ha})$. There were no significant differences in their yields between cultivars Major, Nawiko, Olna , Ika, Tarna, Borostyan and Tisa.

In the year 2003 cultivars Aldana $(1412 \pm 20 \mathrm{~kg} / \mathrm{ha})$, Olna (1761 $\pm 36 \mathrm{~kg} / \mathrm{ha})$, Essor $(2167 \pm 65 \mathrm{~kg} / \mathrm{ha})$, Nawiko $(2167 \pm 94 \mathrm{~kg} / \mathrm{ha})$ and Major $(2174 \pm 14 \mathrm{~kg} / \mathrm{ha})$ were significantly the least productive and significantly the highest yield was reached by the cultivars Borostyan $(4094 \pm 485 \mathrm{~kg} / \mathrm{ha})$ and Tisa $(3565 \pm 72 \mathrm{~kg} / \mathrm{ha})$. There were no significant differences in their yields between cultivars Kador $(2957 \pm 87 \mathrm{~kg} / \mathrm{ha})$, Ika $(3138 \pm 94 \mathrm{~kg} / \mathrm{ha})$ and Tarna $(3217 \pm 145 \mathrm{~kg} / \mathrm{ha})$, but their yield was significantly higher compared to the first five cultivars and significantly lower compared to the yield reached by the cultivar Borostyan.

In the year 2004 significantly the lowest yield was recorded for Aldana $(1185 \pm 55 \mathrm{~kg} / \mathrm{ha})$ and Major $(1754 \pm 507 \mathrm{~kg} / \mathrm{ha})$, significantly the most productive was the cultivar Borostyan $(4337 \pm 18 \mathrm{~kg} / \mathrm{ha})$. There were no significant differences in their mean yields between Major, Olna (2159 $\pm 101 \mathrm{~kg} / \mathrm{ha})$, Nawiko (2510 \pm 78 $\mathrm{kg} / \mathrm{ha})$ and Essor $(2513 \pm 81 \mathrm{~kg} / \mathrm{ha})$, the same was true also for cultivars Nawiko, Essor, Ika $(2955 \pm 129 \mathrm{~kg} / \mathrm{ha})$, Tisa $(3007 \pm 80 \mathrm{~kg} / \mathrm{ha})$, Kador $(3067 \pm 87 \mathrm{~kg} / \mathrm{ha})$ and Tarna $(3275 \pm 145 \mathrm{~kg} / \mathrm{ha})$.

In the year 2005 significantly the lowest yields were recorded for Aldana $(1442 \pm 22 \mathrm{~kg} / \mathrm{ha})$ and Olna $(1760 \pm 22 \mathrm{~kg} / \mathrm{ha})$, with significantly the highest yield the 
cultivar Borostyan $(4341 \pm 77 \mathrm{~kg} / \mathrm{ha})$ stood out. Mean yields of Essor $(2464 \pm 43 \mathrm{~kg} / \mathrm{ha})$, Major $(2471 \pm 399$ $\mathrm{kg} / \mathrm{ha})$, Nawiko (2797 $\pm 58 \mathrm{~kg} / \mathrm{ha})$, Tarna $(2964.8 \pm 80$ $\mathrm{kg} / \mathrm{ha})$, Kador $(3036 \pm 138 \mathrm{~kg} / \mathrm{ha})$ and Ika $(3107 \pm 64$ $\mathrm{kg} / \mathrm{ha}$ ) cultivars were not significantly different one from the other. There were no significant differences also between the yields of Tisa $(3275 \pm 72 \mathrm{~kg} / \mathrm{ha})$, Ika, Kador, Tarna and Nawiko cultivars.

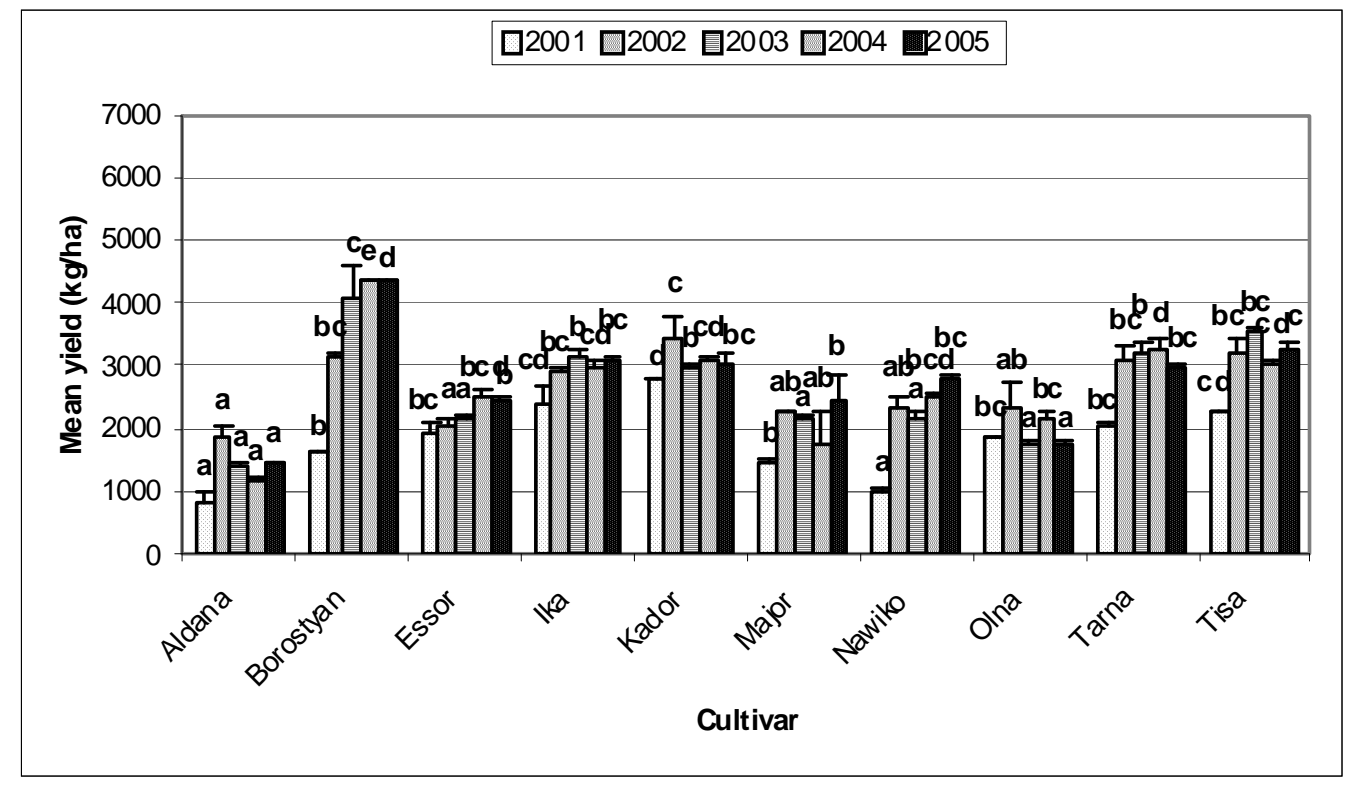

Figure 1: Mean yield ( $\pm S E$ ) of ten soybean cultivars (Glycine max (L.) Merrill) with 8-percent humidity of the grains in the field trials on the experimental field at Biotechnical Faculty in Ljubljana (Slovenia) in the period 2001-2005. Data shown are analysed by multifactor ANOVA followed by Student-Newman-Keuls's multiple range test $(P<0.05)$ for separation of means. Values carrying the same letters do not differ significantly.

\subsection{Yield of cultivars - dense sowing}

With the general analysis of variance we detected a significant influence of the year of the trial and of the cultivar to the mean soybean yield (in both cases $\mathrm{P}<0.05$ ). For the dense sowing of the ten cultivars significantly the highest yield was established for the year $2005(3760 \pm 283 \mathrm{~kg} / \mathrm{ha})$ and significantly the lowest mean yield for the years $2002(3145 \pm 112 \mathrm{~kg} / \mathrm{ha})$ and $2003(3239 \pm 251 \mathrm{~kg} / \mathrm{ha})$. The mean yield of ten soybean cultivars in the year $2004(3567 \pm 312 \mathrm{~kg} / \mathrm{ha})$ was significantly higher than in the two previous years and significantly lower than in 2005 .

Considering the mean yield of soybean in the period $2002-2005$ Tisa cultivar $(5171 \pm 374 \mathrm{~kg} / \mathrm{ha})$ proved to be the most productive one and the lowest yields were given by cultivar Aldana $(2110 \pm 206 \mathrm{~kg} / \mathrm{ha})$. We detected no significant differences between the other two less productive cultivars Major $(2524 \pm 123 \mathrm{~kg} / \mathrm{ha})$ and Olna $(2535 \pm 113 \mathrm{~kg} / \mathrm{ha})$.

The same can be confirmed for the mean yields of medium productive cultivars Nawiko (3047 $\pm 224 \mathrm{~kg} / \mathrm{ha})$, Essor $(3218 \pm 164 \mathrm{~kg} / \mathrm{ha})$ and Ika $(324 \pm 101 \mathrm{~kg} / \mathrm{ha})$, where their mean values were significantly lower from the mean yields given by cultivars Tarna (3627 \pm 205 $\mathrm{kg} / \mathrm{ha})$, Kador $(4285 \pm 413 \mathrm{~kg} / \mathrm{ha})$ and Borostyan
$(4510 \pm 413 \mathrm{~kg} / \mathrm{ha})$. Between the last two cultivars there were no significant differences in their yields and Tarna cultivar was significantly less productive than the other two.

With the individual statistical analysis for the year 2002, we detected no significant differences in the mean yield of ten cultivars (Figure 2). Mean yield values reached from $2587 \pm 71 \mathrm{~kg} / \mathrm{ha}$ (cultivar Nawiko) to $3874 \pm 397$ $\mathrm{kg} / \mathrm{ha}$ (cultivar Tisa). In the year 2003 we confirmed statistically significant $(\mathrm{P}<0.05)$ differences in mean yields of soybean cultivars. Aldana $(2009 \pm 227 \mathrm{~kg} / \mathrm{ha})$, Major $(2246 \pm 217 \mathrm{~kg} / \mathrm{ha})$, Olna $(2268 \pm 94 \mathrm{~kg} / \mathrm{ha})$, Nawiko (2618 \pm 135$)$ and Essor $(2709 \pm 117 \mathrm{~kg} / \mathrm{ha})$ proved to be the least productive cultivars, significantly the highest yield was given by cultivar Tisa (5550 \pm 59 $\mathrm{kg} / \mathrm{ha})$. Also Borostyan (4601 $\pm 109 \mathrm{~kg} / \mathrm{ha})$, Kador $(3717 \pm 239 \mathrm{~kg} / \mathrm{ha})$ and Tarna $(3555 \pm 4 \mathrm{~kg} / \mathrm{ha})$ cultivars could be listed among the more productive cultivars.

In the year 2004 significantly the lowest yield was again recorded for cultivar Aldana (1776 $\pm 6 \mathrm{~kg} / \mathrm{ha})$ and cultivar Tisa $(6471 \pm 297 \mathrm{~kg} / \mathrm{ha})$ was significantly the most productive one. We detected no significant differences between the yields of low to medium productive cultivars - Major (2489 $\pm 69 \mathrm{~kg} / \mathrm{ha})$, Olna $(2594 \pm 14 \mathrm{~kg} / \mathrm{ha})$, Nawiko (2964 $\pm 80 \mathrm{~kg} / \mathrm{ha})$, Essor 
$(2993 \pm 80 \mathrm{~kg} / \mathrm{ha})$ and Ika $(3101 \pm 232 \mathrm{~kg} / \mathrm{ha})$ cultivars could be listed in this group. The mean yield of Borostyan (5058 $\pm 72 \mathrm{~kg} / \mathrm{ha})$ and Kador (4739 \pm 217 $\mathrm{kg} / \mathrm{ha}$ ) cultivars was among the highest during the trials, but significantly lower than the yield given by Tisa.

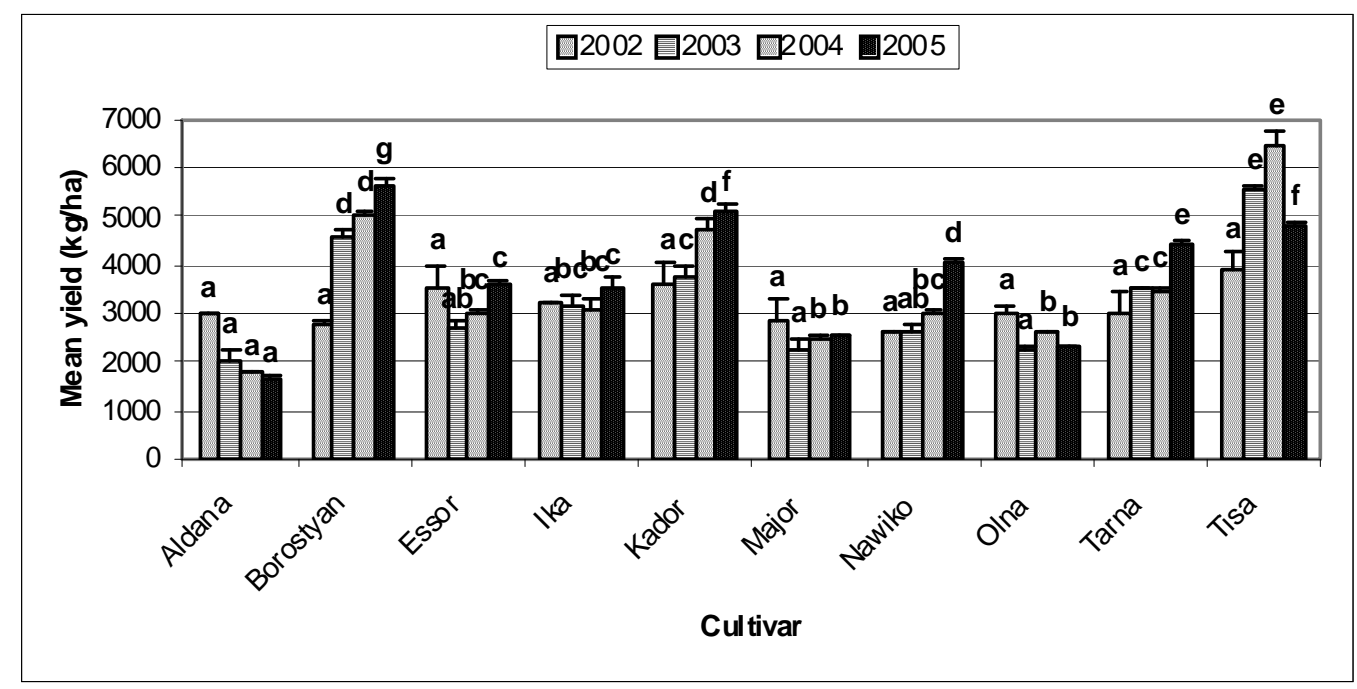

Figure 2: Mean yield ( $\pm S E$ ) of ten soybean cultivars (Glycine max (L.) Merrill) with 8-percent humidity of the grains in the block field trials on the experimental field at Biotechnical Faculty in Ljubljana (Slovenia) in the period 20022005. Data shown are analysed by multifactor ANOVA followed by Student-Newman-Keuls's multiple range test $(P<0.05)$ for separation of means. Values carryng the same letters do not differ significantly.

Table 2: Date of planting and harvesting for ten soybean cultivars (Glycine max (L.) Merrill) in block field trials on the experimental field at Biotechnical faculty in Ljubljana (Slovenia) in the period 2001-2005.

\begin{tabular}{|c|c|c|c|c|c|c|}
\hline \multirow{4}{*}{ Cultivar } & \multicolumn{5}{|c|}{ Date of sowing } & \multirow{4}{*}{$\begin{array}{l}\text { Harvest in the } \\
\text { period } 2001 \text { to } \\
2005\end{array}$} \\
\hline & 14.5 . & 7.5 . & 6.5 & 4.5 . & 5.5 . & \\
\hline & 2001 & 2002 & 2003 & 2004 & 2005 & \\
\hline & \multicolumn{5}{|c|}{ Date of harvest } & \\
\hline Aldana & 4.9 . & 30.8 . & 28.8 . & 29.8 . & 28.8. & 28.8.- 4.9. \\
\hline Borostyan & 27.9. & 27.9. & 14.9. & 16.9 . & 15.9. & 14.9.-27.9. \\
\hline Essor & 27.9. & 27.9. & 14.9 . & 16.9 . & 15.9. & 14. 9.-27.9. \\
\hline Ika & 23.10 . & 21.10. & 15.10 & 18.10. & 17.10. & 15.9.-23.10. \\
\hline Kador & 23.10 . & 21.10 . & 15.10 & 18.10 & 17.10 . & 15.9.-23.10. \\
\hline Major & 11.9. & 17.9. & 14.9. & 16.9. & 15.9. & 11.9.-17.9. \\
\hline Nawiko & 4.9. & 30.8 . & 28.8 . & 29.8. & 28.8. & 28.8.- 4.9. \\
\hline Olna & 27.9 . & 27.9 . & 14.9. & 16.9 . & 15.9. & 14.9.-27.9. \\
\hline Tarna & 27.9. & 17.9. & 14.9 . & 16.9 . & 17.9. & 14.9.-27.9. \\
\hline Tisa & 23.10 . & 25.10 . & 15.10 . & 20.10 & 19.10. & 15.9.-25.10. \\
\hline
\end{tabular}

Cultivar Aldana had significantly the lowest yield $(1651 \pm 43 \mathrm{~kg} / \mathrm{ha})$ also in the year 2005 , when Borostyan $(5644 \pm 153 \mathrm{~kg} / \mathrm{ha})$ was the most productive cultivar. Olna $(2304 \pm 43 \mathrm{~kg} / \mathrm{ha})$ and Major $(2513 \pm 49 \mathrm{~kg} / \mathrm{ha})$ were significantly more productive than cultivar Aldana, but still less productive than Ika $(3522 \pm 188 \mathrm{~kg} / \mathrm{ha})$ and Essor $(3616 \pm 22 \mathrm{~kg} / \mathrm{ha})$ and there was no significant differences between the two. According their productivity also Nawiko $(4021 \pm 138 \mathrm{~kg} / \mathrm{ha})$, Tarna $(4434 \pm 88 \mathrm{~kg} / \mathrm{ha})$, Tisa $(4790 \pm 51 \mathrm{~kg} / \mathrm{ha})$ and Kador . There was the difference of 48 to 55 days between the harvest of the earliest and the latest cultivars.
$(5109 \pm 109 \mathrm{~kg} / \mathrm{ha})$ cultivars can be listed into the top half of the list.

In every year of the trials, the most early cultivars were Aldana and Nawiko with mean growing period of 115 days, 15 to 20 days later were Borostyan, Essor, Major, Olna and Tarna cultivars with the mean growing period of 135 days, approximately one month later the latest cultivars Ika, Kador and Tisa matured, in the mean remaining on the field for 166 days. 
Table 3: The length of the growing period for ten soybean cultivars (Glycine max (L.) Merrill) in block field trials on the experimental field at Biotechnical Faculty in Ljubljana (Slovenia) in the period 2001-2005.

\begin{tabular}{|l|c|c|c|c|c|c|}
\hline \multirow{2}{*}{ Cultivar } & \multicolumn{5}{|c|}{ Length of the growing period (days) } & \multirow{2}{*}{$\begin{array}{c}\text { Mean growing period } \\
\text { (days) }\end{array}$} \\
\cline { 2 - 6 } & 2001 & 2002 & 2003 & 2004 & 2005 & 115 \\
\hline Aldana & 113 & 116 & 114 & 117 & 115 & 135.6 \\
\hline Borostyan & 136 & 143 & 131 & 135 & 133 & 135.6 \\
\hline Essor & 136 & 143 & 131 & 135 & 133 & 164.6 \\
\hline Ika & 162 & 167 & 162 & 167 & 165 & 164.6 \\
\hline Kador & 162 & 167 & 162 & 167 & 165 & 130.4 \\
\hline Major & 120 & 133 & 131 & 135 & 133 & 115 \\
\hline Nawiko & 113 & 116 & 114 & 117 & 115 & 135.6 \\
\hline Olna & 136 & 143 & 131 & 135 & 133 & 134 \\
\hline Tarna & 136 & 133 & 131 & 135 & 135 & 166.2 \\
\hline Tisa & 162 & 171 & 162 & 169 & 167 & \\
\hline
\end{tabular}

Compared to the growing period for soybean stated by Gagro (1997) and UPOV (1998), we can range Aldana and Nawiko cultivars into the medium early maturity class with the growing period of 110 to 120 days; Borostyan, Essor, Major, Olna and Tarna cultivars into medium late maturity class (120 to 130 days) or late maturity class (130 to 140 days) and cultivars Ika, Kador and Tisa can be listed as very late with the growing period of 160 to 170 days.

High oscillations in mean daily temperature and mean quantity of precipitations, which were above the long term mean, affected the length of the growing period in the 2002, when the length of the growing period most deviated from values for other years, which resulted in late ripeness for most of the tested cultivars. The greatest deviations were recorded for Borostyan, Essor and Olna, which were »late« for 7 to 12 days; but the length of the growing period for the earliest and the latest cultivars did not differ much from the data for other years. In the dry year of 2001 two cultivars were earlier with ripening - Aldana, which was harvested 4 days earlier than usually and the growing period of Major was for 11 to 15 days shorter.

\section{CONCLUSION}

Results from the field trials with ten soybean cultivars in the period from 2001 to 2005 show important differences in productivity of the cultivars when sown to $50 \mathrm{~cm}$ row spacing (wide rows) compared to the row spacing of $25 \mathrm{~cm}$ (narrow rows), in the length of the growing period of individual cultivars and also the differences between individual years were detected.

When studying the influence of the row spacing on the yield of crop in the period 2002-2005, significantly higher yield (with $\mathrm{P}<0.05$ ) of all soybean cultivars was detected when using the dense sowing (3428 kg/ha) compared to the thin sowing where the mean yield was $2690 \mathrm{~kg} / \mathrm{ha}$, at the same time with the thin sowing we had more work mechanically destructing the weeds.

Differences between mean yields of cultivars for dense sowing compared to the thin sowing depended on the cultivar; yields using the dense sowing were higher for $219 \mathrm{~kg} / \mathrm{ha}$ (Ika) and all up to $1910 \mathrm{~kg} / \mathrm{ha}$ (Tisa), that means that the longer row spacing also had an influence on the productivity of late soybean cultivars like Ika and Tisa.
A significant influence of the cultivar on the yield $(\mathrm{P}<0.05)$ was also shown in every year for the thin sowing, where the yield in 2001 (year of the drought) was significantly lower compared to other years. The most productive cultivar for the thin sowing was Borostyan (3974 kg/ha) and the lowest yield was recorded for Aldana cultivar (1472 kg/ha).

For the dense sowing with $\mathrm{P}<0.05$ we have confirmed significantly the highest yield of soybean in the year $2005(3760 \mathrm{~kg} / \mathrm{ha})$, compared to the years 2002 (3145 $\mathrm{kg} / \mathrm{ha}$ ) and 2003 (3239 kg/ha), when the yields were significantly lower. Cultivar Aldana $(2110 \mathrm{~kg} / \mathrm{ha}) \mathrm{had}$ the lowest yield of grains also for the dense sowing, while under the same growing conditions, cultivar Tisa $(5171 \mathrm{~kg} / \mathrm{ha})$ was the most productive one.

Regardless of the row spacing the most productive cultivars proved to be Tisa, Borostyan and Kador with mean crop yield calculated from 3700 to $4200 \mathrm{~kg}$ grains/ha, medium productive are the cultivars Essor, Ika, Nawiko and Tarna (2700 do $3400 \mathrm{~kg}$ grains/ha), the 
calculated yield of Major and Olna cultivars was approximately $2500 \mathrm{~kg} / \mathrm{ha}$, and the lowest yield was given by Aldana cultivar (1800 kg/ha).

Regarding the length of the growing period we could recommend medium late to late cultivars Borostyan, Essor, Tarna, Major and Olna with the growing period of 131 to 143 days and medium early cultivar Nawiko, which remained on the field for 113 to 117 days, as suitable for sowing in central parts of Slovenia; considering their productivity Nawiko and Borostyan proved to be the most promising cultivars from each of their maturity group. Damp grains and leafs can hinder or prevent machine harvesting of very late cultivars Ika, Kador and Tisa with the growing period of 162 to 171 days, therefore despite their high productivity their production can be very risky.

For the production - there is no need for the introduction of cultivars Aldana, Borostyan, Essor, Ika, Nawiko and
Tarna, which are all listed in the Common catalogue of the European Union; other cultivars that are not registered in any EU member state should be registered before their production in Slovenia.

It is our opinion that soybean is an arable crop with good potential for organic farming, for the production of protein animal feed and for alternative nutrition for humans. Higher variety of plants in production is the only way to realise the National strategic plan of rural development 2007-2013, where an important role is given to the crop rotation, mostly for the reduction of the role of maize monoculture (incidence of maize beetle) and for the improvement of cereal crop rotation maize-wheat (barley), which is becoming more common due to reduced production of root and tuber crops on Slovene fields.

\section{REFERENCES}

Carlson, J. B. (1973): Morphology. In: Soybeans: Improvement, production, and uses. Caldwel B. E. (ed.). Wisconsin, USA, American Society of Agronomy, Inc.: 17-66.

Čremožnik, B. (2004): Ločevanje sort soje (Glycine max (L.) Merrill) na podlagi morfoloških deskriptorjev. Dipl. delo. Univ. v Ljubljani, Biotehniška fakulteta, Odd. za agronomijo: $59 \mathrm{p}$.

Devlin, D. L. (1995): Row spacing and seeding rates for soybean in low and high yielding environments. Journal of Production Agriculture, 8, 2: 143-146.

Elmore, R. W. (1998): Soybean Cultivar Responses to Row Spacing and Seeding Rates in Rainfed and Irrigated Environments. In: Journal of Production Agriculture, 11, 3: 326-331.

Gagro, M. (1997): Soja (Glycine hispida (Moench) Max). In: Ratarstvo obiteljskoga gospodarstva: Žitarice i zrnate mahunice. Zagreb, Hrvatsko agronomsko društvo: 207222 .

Guidlines for conduct of test for distinctness, uniformity and stabilty. (1998): Soybean (Glycine $\max$ (L.) Merr.). TG/80/6. Geneva, UPOV: $38 \mathrm{p}$.

Holshouser, D. L., Whittaker, J. P. (2002): Plant population and row-spacing effects on early soybean production system in the mid-atlantic USA. Agronomy Journal, 94: 603-611.

Ileršič, J., Dolničar, P., Ugrinović, K., Verbič, J. (2000): Preizkušanje razločljivosti, izenačenosti in nespremenljivosti (RIN) sort rastlin. In: Novi izzivi v poljedelstvu 2000. Moravske toplice, 14. in 15. december 2000. Ljubljana, Tajnšek A., Šantavec I. (ur.). Slovensko agronomsko društvo: 156-160.

Kocjan Ačko, D., Tolar Š., Šantavec, I. (2005): Stročnice v kolobarju slovenskih ekoloških kmetij. In: Acta agriculturae Slovenica, 85-1: 125-134.

Kocjan Ačko, D. (2005): Soja. Vodilna na svetu, zapostavljena pri nas. V: Delo, znanost, 21. julij 205: 18.

Lueschen, W. E. (1992): Tillage, row spacing, and planting date effects on Soybeans. N. C. E. S. Tech. Bul. 197.

Mesečni agrometeorološki bilten. Agencija RS za okolje 2001 do 2005 .

Moore, S. H. (1991): Uniformity of plant spacing effect on soybean population parameters. In: Crop science, 31: 1049-1051.

Pedersen, P., Lauer, J. G. (2003): Corn and soybean response to rotation sequence, row spacing, and tillage systems. In: Agronomy Journal, 95: 965-971.

Štepic, P. (2004): Vpliv gostote setve na pridelek desetih sort soje (Glycine $\max ($ L.) Merrill). Dipl. delo. Univ. V Ljubljani, Biotehniška fakulteta, Odd. za agronomijo: 41 p.

Vratarić, M. (1986): Proizvodnja soje. Sarajevo, Zadrugar: 1228 